Check for updates

Cite this: RSC Adv., 2018, 8, 37184

\title{
Novozym 40086 as a novel biocatalyst to improve benzyl cinnamate synthesis
}

\begin{abstract}
Shangde Sun (D) * and Liya Tian (D)
Benzyl cinnamate is one of the derivatives of cinnamic acid, which can be used as the main constituent in perfume, UV filters and medicines. In this work, several commercial immobilized lipases (Novozym 40086, Novozym 435 and Lipozyme TLIM) and free lipases (lipase A and B from Candida sp., and lipozyme from Thermomyces linuginosous) were used as catalysts for benzyl cinnamate preparation by the esterification of benzyl alcohol with cinnamic acid. The effect of various esterification parameters (reaction time, reaction temperature, lipase concentration and substrate ratio) on benzyl cinnamate yield were also optimized and evaluated using response surface methodology (RSM). Among all tested lipases, Novozym 40086, as a new commercial immobilized lipase from Rhizomucor miehei immobilized on acrylic resin beads, showed the best activity for the esterification. Esterification parameters were optimized as follows: reaction temperature $46.3{ }^{\circ} \mathrm{C}$, substrate molar ratio $1: 3$ (cinnamic acid/benzyl alcohol), Novozym 40086 concentration $23.1 \mathrm{mg} \mathrm{mL}^{-1}$, reaction time $11.3 \mathrm{~h}$, and maximum benzyl cinnamate yield $(96.2 \pm 1.4 \%)$ were achieved under the optimal conditions. Novozym 40086 can be reused 9 times without significant decrease in benzyl cinnamate yield ( $90.1 \%$ yield after nine times). The activation energy for the Novozym 40086-catalyzed esterification was $14.96 \pm 0.25 \mathrm{~kJ} \mathrm{~mol}^{-1}$. These results showed that Novozym 40086 was a novel and efficient biocatalyst for the esterification, which can be used as a good alternative for benzyl cinnamate production.
\end{abstract}

Received 11th October 2018

Accepted 31st October 2018

DOI: $10.1039 / \mathrm{c} 8 \mathrm{ra0} 8433 \mathrm{e}$

rsc.li/rsc-advances biocatalysts, the carrier features can affect the activity and stability of immobilized enzymes. ${ }^{17-21}$ Because the carrier of Lipozyme TLIM was silica gel, which can be easily destroyed during the mechanical mixing process and in the presence of by-product water formed in the esterification, the activity of Lipozyme TLIM decreased to $63 \%$ after reuse 3 times. Therefore, more efficient biocatalysts, especially for the immobilized enzymes, have been more popular alternative for benzyl cinnamate preparation.

In this study, for enhancing benzyl cinnamate synthesis, several commercial immobilized lipases (Novozym 40086, Novozym 435, Lipozyme TLIM) and free lipases (lipase A and B from Candida sp., and lipozyme from Thermomyces linuginosous) were used to catalyze the esterification. Effects of esterification parameters (reaction time, temperature, lipase concentration and substrate ratio) on the reaction were evaluated and optimized by RSM, and the lipase reusability was also investigated. HPLC-UV and HPLC-ESI-MS were used to analyze benzyl cinnamate synthesis. Thermodynamic and reaction kinetic were investigated.

\section{Materials and methods}

\subsection{Materials}

Cinnamic acid was provided from Nanjing Zelang Chemical Co., Ltd. (Nanjing China). Benzyl alcohol was purchased from 
Maikelin Biochem. Technol. Co., Ltd. (Shanghai China). Three commercial immobilized lipases (Novozym 40086, Novozym 435 and Lipozyme TLIM) and three free lipases (lipase A and B from Candida sp., and lipozyme from Thermomyces linuginosous) were purchased from Novozymes A/S (Bagsvaerd, Denmark).

\subsection{Enzymatic esterification and immobilized enzyme reusability}

The esterification of cinnamic acid $(0.1 \mathrm{mmol})$ with benzyl alcohol $(0.3 \mathrm{mmol})$ was carried out in $10 \mathrm{~mL}$ isooctane at $150 \mathrm{rpm}$ and $40{ }^{\circ} \mathrm{C}$. The esterification was initialized when lipase was added. Samples $(20 \mu \mathrm{L})$ were taken out for analysis at specific time intervals.

To investigate the reusability of lipase, after the esterification finished, Novozym 40086 was firstly filtered, and then washed using isooctane for 6 times. Finally, the lipase was dried for the next use.

\subsection{Analysis}

Products were analyzed using HPLC with C18 column $(250 \mathrm{~mm}$ $\times 4.6 \mathrm{~mm}, 5 \mu \mathrm{m})$, which was eluted with solvent $10 \% \mathrm{~A}(0.5 \%$, v/ $\mathrm{v}$, glacial acetic acid/water) and solvent $90 \% \mathrm{~B}$ (methanol) at 0.5 $\mathrm{mL} \min ^{-1}$ at $35^{\circ} \mathrm{C}$ and $280 \mathrm{~nm}$.

In order to identify the product, the major ion $\left([\mathrm{M}+\mathrm{Na}]^{+}\right)$of benzyl cinnamate detected by HPLC-ESI-MS was 261 (required M 238). The capillary, collision and cone voltages were $3.0 \mathrm{kV}, 5 \mathrm{~V}$ and $30 \mathrm{~V}$, respectively. The ion source and desolvation temperatures were $80{ }^{\circ} \mathrm{C}$ and $150{ }^{\circ} \mathrm{C}$, respectively. The flows of cone desolvation gas, desolvation gas and injection were $40 \mathrm{~L} \mathrm{~h}^{-1}, 350 \mathrm{~L} \mathrm{~h}^{-1}$ and $20 \mu \mathrm{L} \mathrm{min}^{-1}$, respectively.

\subsection{Experimental design for response surface methodology}

A Box-Behnken design with 3 levels and 3 factors was used to evaluate the interaction of factors on the esterification (Table 1). Three factors and 3 levels were set as esterification temperature $\left(20^{\circ} \mathrm{C}, 40^{\circ} \mathrm{C}\right.$ and $\left.60^{\circ} \mathrm{C}\right)$, esterification time ( $3 \mathrm{~h}, 9 \mathrm{~h}$ and $\left.15 \mathrm{~h}\right)$, and lipase concentration $\left(5 \mathrm{mg} \mathrm{mL}^{-1}, 20 \mathrm{mg} \mathrm{mL}^{-1}\right.$ and $35 \mathrm{mg}$ $\mathrm{mL}^{-1}$ ), respectively.

\subsection{Statistical analysis}

From the RSM design, the mathematical relationship between esterification parameters with benzyl cinnamate yield was as follow:

$$
Y=\beta_{0}+\sum_{i=1}^{3} \beta_{i} \mathrm{X}_{i}+\sum_{i=1}^{3} \beta_{i i} X_{i}^{2}+\sum_{i=1}^{2} \sum_{j=i+1}^{3} \beta_{i j} \mathrm{X}_{i} \mathrm{X}_{j}
$$

where $Y$ is benzyl cinnamate yield, $X_{i}$ and $X_{j}$ represent reaction parameters, and $\beta_{0}, \beta_{i}, \beta_{i i}$, and $\beta_{i j}$ are the constants.

\section{Results and discussion}

\subsection{Biocatalyst screening}

Fig. 1 shows that, when the three free lipases were used as biocatalysts for the esterification, the low benzyl cinnamate yields were obtained, which were attributed to the aggregation of free liquid lipases in isooctane system. Fig. 1 also shows that, at $24 \mathrm{~h}$, the maximum benzyl cinnamate yield ( $92.3 \pm 2.3 \%$ ) was obtained using Novozym 40086 as biocatalyst, which was 1.7 times that $(55.1 \pm 1.6 \%)$ of Lipozyme TLIM and 1.8 times that $(51.3 \pm 2.3 \%)$ of free lipozyme from Thermomyces linuginosous. In the previous reports, ${ }^{10,12}$ immobilized lipase Lipozyme TLIM was used to prepare benzyl cinnamate. However, the immobilized carrier of Lipozyme TLIM was silica gel, which can be easily destroyed during the mixing process by mechanical

Table 1 RSM design and results of Novozym 40086-catalyzed the esterification for benzyl cinnamate preparation

\begin{tabular}{|c|c|c|c|c|}
\hline Treatment no. ${ }^{a}$ & $\begin{array}{l}\text { Reaction time } \\
\mathrm{A}(\mathrm{h})\end{array}$ & $\begin{array}{l}\text { Novozym } 40086 \\
\text { concentration B }\left(\mathrm{mg} \mathrm{mL}^{-1}\right)\end{array}$ & $\begin{array}{l}\text { Temperature } \\
\mathrm{C}\left({ }^{\circ} \mathrm{C}\right)\end{array}$ & $\begin{array}{l}\text { Benzyl cinnamate } \\
\text { yield }(\%)\end{array}$ \\
\hline 1 & $9(0)$ & $20(0)$ & $40(0)$ & $89.2 \pm 1.20$ \\
\hline 2 & $9(0)$ & $20(0)$ & $40(0)$ & $91.0 \pm 0.82$ \\
\hline 3 & $3(-1)$ & $20(0)$ & $20(-1)$ & $24.1 \pm 1.61$ \\
\hline 4 & $3(-1)$ & $35(1)$ & $40(0)$ & $64.3 \pm 0.60$ \\
\hline 5 & $15(1)$ & $35(1)$ & $40(0)$ & $91.4 \pm 0.42$ \\
\hline 6 & $15(1)$ & $20(0)$ & $20(-1)$ & $88.6 \pm 1.12$ \\
\hline 7 & $3(-1)$ & $5(-1)$ & $40(0)$ & $67.9 \pm 0.63$ \\
\hline 8 & $9(0)$ & $20(0)$ & $40(0)$ & $92.0 \pm 1.56$ \\
\hline 9 & $9(0)$ & $35(1)$ & $60(1)$ & $92.3 \pm 0.61$ \\
\hline 10 & $15(1)$ & $5(-1)$ & $40(0)$ & $74.0 \pm 0.31$ \\
\hline 11 & $3(-1)$ & $20(0)$ & $60(1)$ & $94.2 \pm 1.46$ \\
\hline 12 & $9(0)$ & $5(-1)$ & $20(-1)$ & $28.0 \pm 1.62$ \\
\hline 13 & $9(0)$ & $5(-1)$ & $60(1)$ & $93.0 \pm 1.19$ \\
\hline 14 & $15(1)$ & $20(0)$ & $60(1)$ & $90.8 \pm 2.19$ \\
\hline 15 & $9(0)$ & $20(0)$ & $40(0)$ & $88.8 \pm 0.52$ \\
\hline 16 & $9(0)$ & $35(1)$ & $20(-1)$ & $75.2 \pm 1.78$ \\
\hline 17 & $9(0)$ & $20(0)$ & $40(0)$ & $85.8 \pm 1.19$ \\
\hline
\end{tabular}

${ }^{a}$ Experiment numbers randomly. 
agitation and the presence of water formed in the esterification. ${ }^{22,23}$ These resulted in the decrease of benzyl cinnamate yield to $63 \%$ at three times reuse of Lipozyme TLIM. ${ }^{10,12}$ Novozym 40086 was a new commercial lipase from Rhizomucor miehei immobilized on acrylic resin beads, which was very stable and easily separated from the esterification, and the maximum benzyl cinnamate yield $(92.3 \pm 2.3 \%)$ was achieved using Novozym 40086 as biocatalyst. Therefore, compared with other commercial immobilized lipases and free lipases used in the work, Novozym 40086 was the best alternative for the esterification, which was ascribed to the interfacial activation of the immobilized hydrophobic carrier (acrylic resin beads) and stabilization of open form of lipase by the immobilization. Similar effect of hydrophobic supports on the immobilized enzyme activity can also be found in other lipases. ${ }^{19,20,24,25}$

\subsection{Selection of solvent}

Fig. 2 shows that, among the tested five solvents, high benzyl cinnamate yields can be obtained using isooctane $(\log P, 4.5)$, heptane $(\log P, 4.0)$ and hexane $(\log P, 3.5)$ as solvents. These were attributed to the presence of non-polar solvents with high $\log P(>3.0)$. Similar the enhancement of immobilized enzyme activity in non-polar solvent can also be found in other reactions. ${ }^{26-29}$ However, when heptane, hexane and toluene were used as solvents, the maximum benzyl cinnamate yields were obtained at $12 \mathrm{~h}$, and with further increase of reaction time to $24 \mathrm{~h}$, benzyl cinnamate yield decreased, which may be attributed to the dilution of cinnamic acid with reaction progress and more water into the reaction system from the atmosphere. Similar effect can also be found in other enzymatic esterification. $^{22,23}$
From Fig. 2, we can found that the maximum benzyl cinnamate yield (97.1 $\pm 1.38 \%)$ was successfully achieved using isooctane as solvent, which was attributed the high boiling point $\left(99^{\circ} \mathrm{C}\right)$ and $\log P(4.5)$ of isooctane. However, for the polar chloroform $(\log P, 2.0)$, the lowest benzyl cinnamate yield (less than $70 \%$ ) was obtained, which was due to the fact that the essential water on the surface of immobilized enzyme was deprived by the polar chloroform. Similar immobilized enzyme activity decreased in polar solvents can also be found in many reactions..$^{30-32}$

\subsection{Effect of substrate ratio}

Varying substrate ratio from 1:1 (cinnamic acid to benzyl alcohol, mol mol${ }^{-1}$ ) to $1: 3$, benzyl cinnamate yield increased from $83.2 \pm 2.19 \%$ to $93.5 \pm 1.29 \%$ at $24 \mathrm{~h}$ (Fig. 3). However, with the substrate molar ratio ranging from $1: 4$ to $1: 6$, the yield of benzyl cinnamate decreased from $87.4 \pm 2.06 \%$ to 86.3 $\pm 2.0 \%$ at $24 \mathrm{~h}$, which were attributed to the decrease of the concentration of cinnamic acid and more dead end enzymebenzyl alcohol complex formation with the increase of benzyl alcohol concentration. These indicated that, at high benzyl alcohol concentration, the inhibition of benzyl alcohol on the immobilized lipase-catalyzed esterification was significant. Similar inhibition of alcohol on lipase activity can also be found in another reaction. ${ }^{33-36}$

\subsection{Effect of Novozym 40086 concentration}

According to the previous methods, ${ }^{34,37,38}$ the initial reaction rates, defined as the initial benzyl cinnamate yield $(\leq 15.0 \%$ benzyl cinnamate yield) per unit time $\left(V_{0}, \operatorname{mol}\left(\mathrm{L}^{-1} \mathrm{~min}^{-1}\right)\right)$,

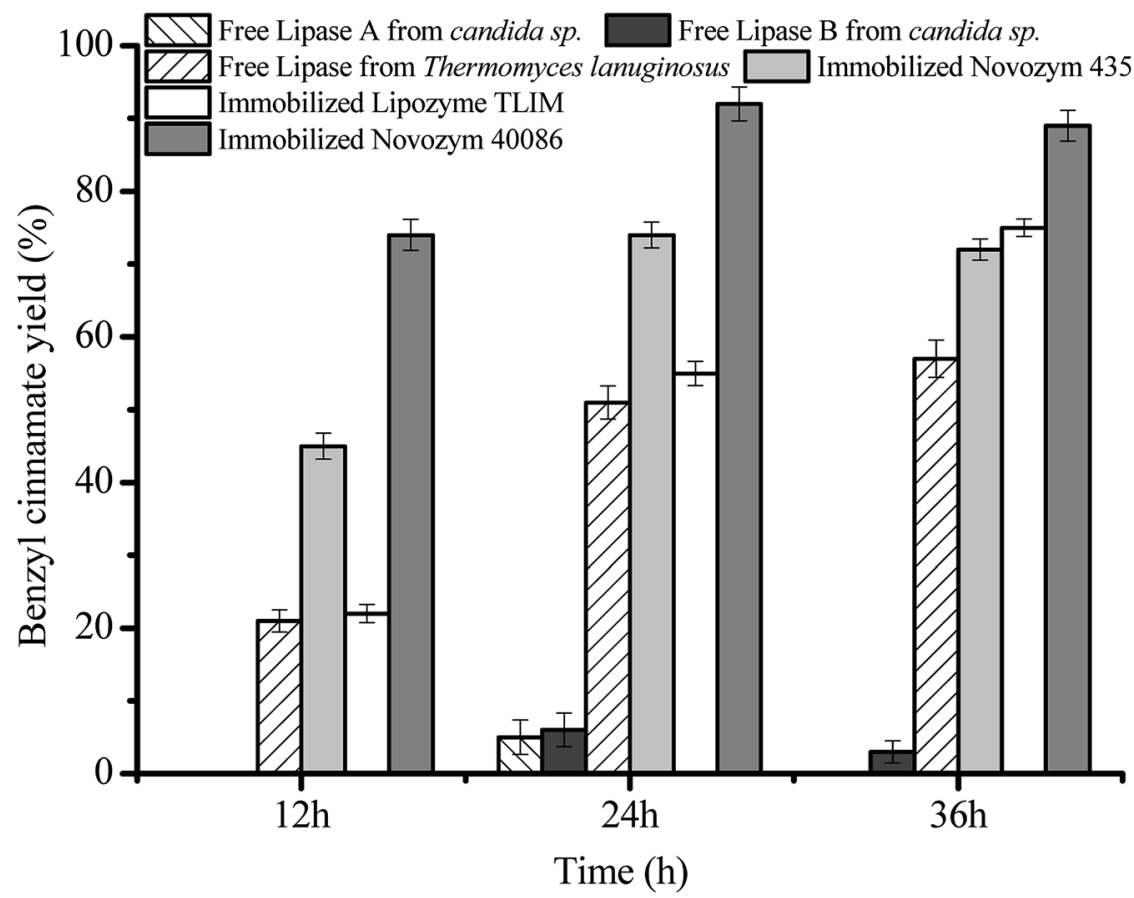

Fig. 1 Effect of different lipases on benzyl cinnamate yield. Reaction conditions: substrate ratio $1: 3$ (cinnamic acid to benzyl alcohol, mol $\mathrm{mol}^{-1}$ ), lipase concentration $30 \mathrm{mg} \mathrm{mL}^{-1}$ at $150 \mathrm{rpm}$ and $40{ }^{\circ} \mathrm{C}$ in isooctane. 


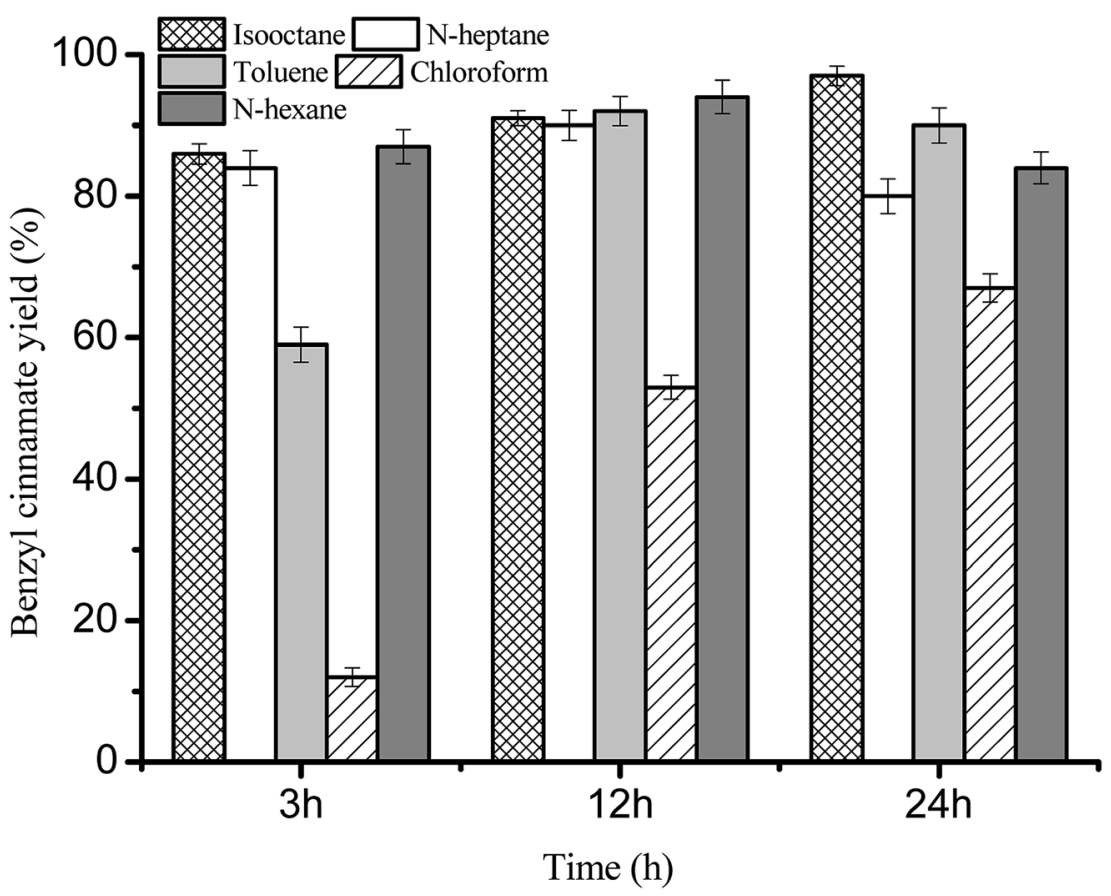

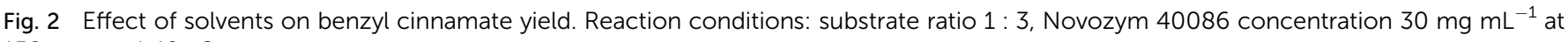
$150 \mathrm{rpm}$ and $40^{\circ} \mathrm{C}$.

were calculated from six experimental points of the yield-time profile, where the profiles were found to be approximately linear. Fig. 4 shows that, with the increase of Novozym 40086 concentration, the time to achieve equilibrium was shortened from $>24 \mathrm{~h}\left(5 \mathrm{mg} \mathrm{mL}^{-1}\right)$ to $9 \mathrm{~h}\left(30 \mathrm{mg} \mathrm{mL}^{-1}\right)$, and the initial formation rate of benzyl cinnamate linearly increased from 1.8 $\times 10^{-3} \mathrm{~mol}\left(\mathrm{~L}^{-1} \mathrm{~min}^{-1}\right)$ to $8.8 \times 10^{-3} \mathrm{~mol}\left(\mathrm{~L}^{-1} \mathrm{~min}^{-1}\right)$. These results indicated that, at lower Novozym 40086 concentration $\left(<30 \mathrm{mg} \mathrm{mL}{ }^{-1}\right)$, the effect of external mass transfer can be neglected, and similar effect can also be confirmed by the effect of rotation rate (Fig. 5). However, at higher Novozym 40086

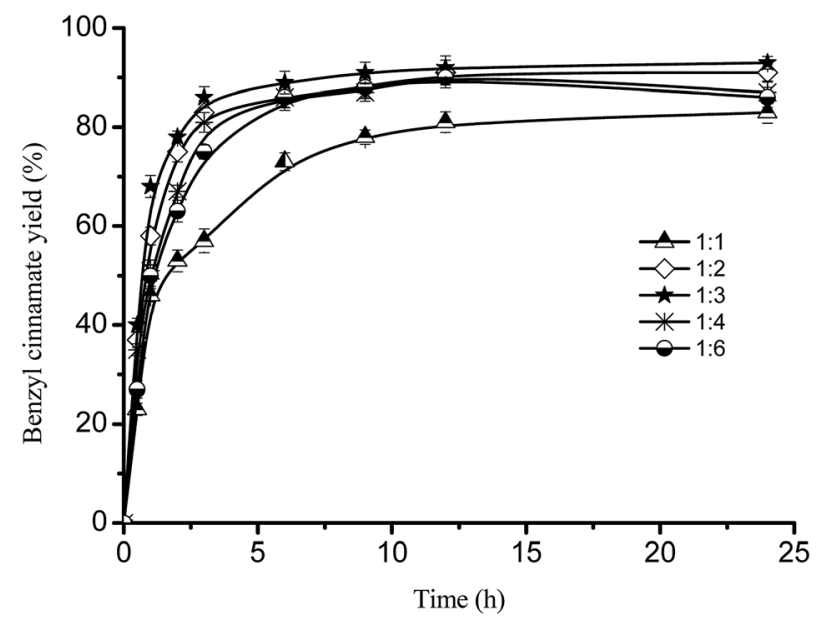

Fig. 3 Effect of substrate ratio on benzyl cinnamate yield. Reaction conditions: Novozym 40086 concentration $30 \mathrm{mg} \mathrm{mL}^{-1}$ at $150 \mathrm{rpm}$ and $40^{\circ} \mathrm{C}$ in isooctane. concentration, the presence of more solid immobilized lipase resulted in the diffusional limitation and the water in the reaction system wasn't enough for the immobilized lipase activity, which can slightly decrease benzyl cinnamate yield. Similar results of immobilized biocatalysts on the mass transfer can also be found in other studies. . $^{10,34,36,37,39,40}$

Fig. 5 shows that there was not significant influence of rotation rate on the reaction, which indicated that the esterification wasn't controlled by external mass transfer. These were agreed with the results of lipase concentration. Similar effect of the excess immobilized biocatalysts on the mass transfer can also be found in other reactions. ${ }^{17,34,36,37,40,41}$

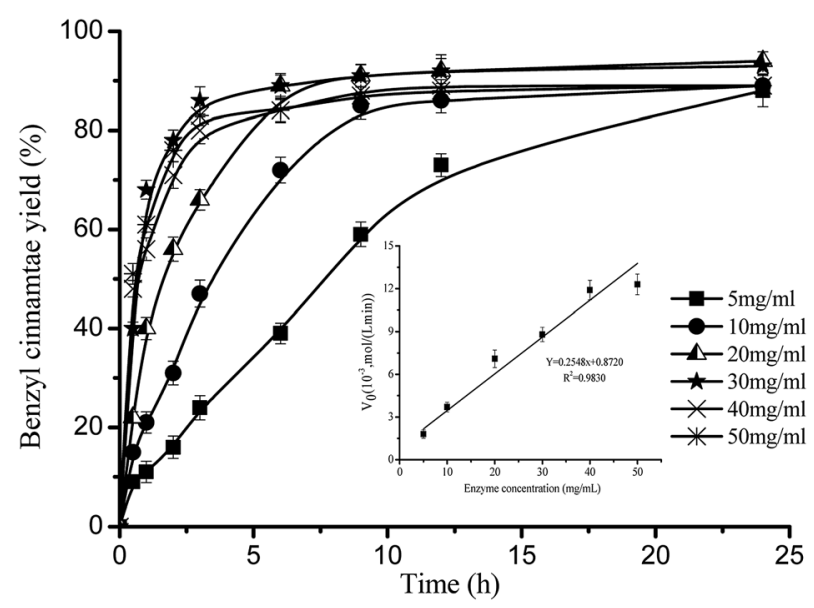

Fig. 4 Effect of Novozym 40086 concentration on benzyl cinnamate yield. Reaction conditions: substrate ratio $1: 3$ at $150 \mathrm{rpm}$ and $40^{\circ} \mathrm{C}$ in isooctane. 


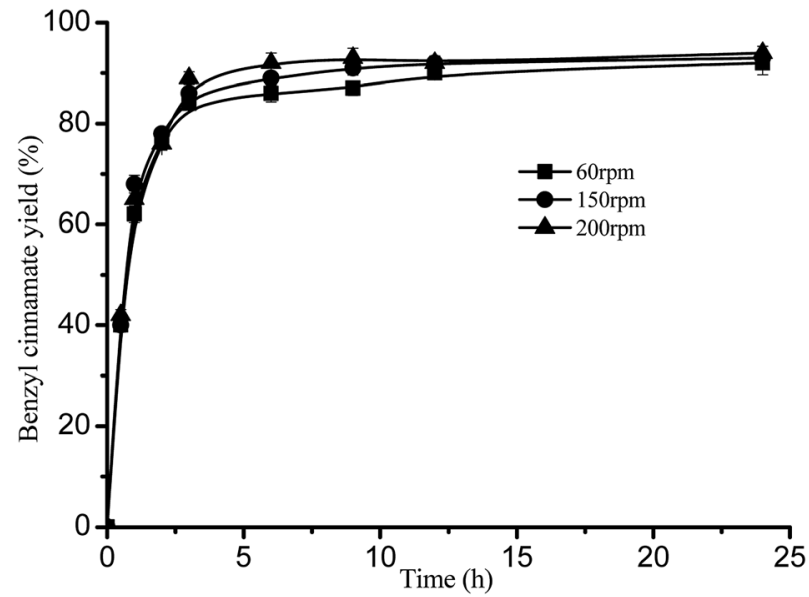

Fig. 5 Effect of rotation rate on benzyl cinnamate yield. Reaction conditions: substrate ratio $1: 3$ and Novozym 40086 concentration $30 \mathrm{mg} \mathrm{mL}^{-1}$ at $40{ }^{\circ} \mathrm{C}$ in isooctane.

\subsection{Effect of esterification temperature}

Due to the low boiling point $\left(99^{\circ} \mathrm{C}\right)$ of isooctane as reaction solvent and the volatility of benzyl alcohol (flash point, $100{ }^{\circ} \mathrm{C}$ ), the highest reaction temperature was set as $70{ }^{\circ} \mathrm{C}$.

Fig. 6 shows that, as the temperature increases from $20{ }^{\circ} \mathrm{C}$ to $60{ }^{\circ} \mathrm{C}$, the formation rate of benzyl cinnamate rapidly increased, for example, initial esterification rate increased from $5.8 \times$ $10^{-3} \mathrm{~mol}\left(\mathrm{~L}^{-1} \mathrm{~min}^{-1}\right)$ of $20{ }^{\circ} \mathrm{C}$ to $1.54 \times 10^{-2} \mathrm{~mol}\left(\mathrm{~L}^{-1} \mathrm{~min}^{-1}\right)$ of $70{ }^{\circ} \mathrm{C}$, and time to achieve equilibrium was shortened from $>24 \mathrm{~h}\left(\right.$ at $\left.20^{\circ} \mathrm{C}\right)$ to $3 \mathrm{~h}\left(\right.$ at $\left.70{ }^{\circ} \mathrm{C}\right)$. These indicated that the high thermodynamic stability of the immobilized Novozym 40086. Fig. 6 also shows that, as the temperature increases, the maximum benzyl cinnamate yield increased from $77.5 \pm 2.3 \%$ of $20{ }^{\circ} \mathrm{C}$ to $92.6 \pm 2.06 \%$ of $70{ }^{\circ} \mathrm{C}$. These results was attributed to that, the esterification is an endothermic reaction, and the increase of temperature can increase the active molecules of the substrates and decrease the viscosity of reaction system, which

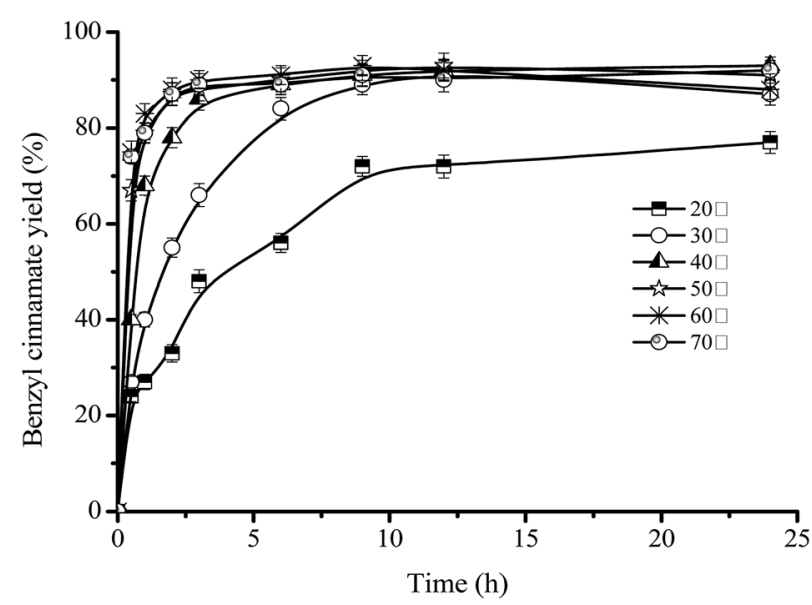

Fig. 6 Effect of esterification temperature on benzyl cinnamate yield Reaction conditions: substrate ratio 1 : 3, Novozym 40086 concentration $30 \mathrm{mg} \mathrm{mL}^{-1}$ at $150 \mathrm{rpm}$ in isooctane.

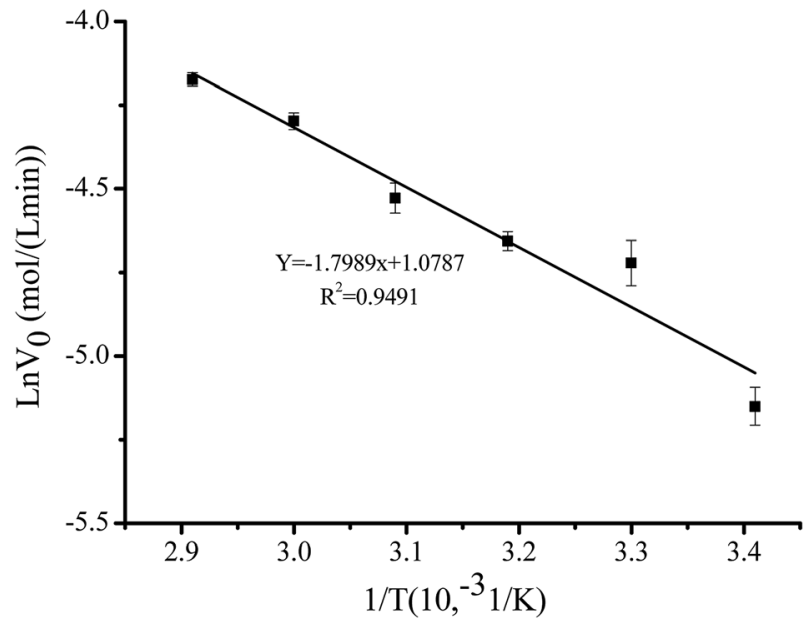

Fig. 7 Relationship between initial esterification rate with temperature. Reaction conditions: substrate ratio 1:3, Novozym 40086 concentration $30 \mathrm{mg} \mathrm{mL}^{-1}$ at $150 \mathrm{rpm}$ in isooctane.

is beneficial to more energetic collisions of the substrates to form benzyl cinnamate. Similar effect of temperature can also be found in other enzyme-catalyzed reactions. ${ }^{42-46}$

\subsection{Reaction thermodynamics and kinetics}

Fig. 7 shows that initial reaction rate linearly increased with temperature ranging from $20{ }^{\circ} \mathrm{C}$ to $70{ }^{\circ} \mathrm{C}$. $E_{\mathrm{a}}$ of Novozym 40086 catalyzed the reaction was $14.96 \pm 0.25 \mathrm{~kJ} \mathrm{~mol}^{-1}$, which was higher than that $\left(12.8 \pm 0.1 \mathrm{~kJ} \mathrm{~mol}^{-1}\right)$ of the benzyl propionate preparation using immobilized lipase as catalyst and lower than that $\left(16.6 \pm 0.7 \mathrm{~kJ} \mathrm{~mol}^{-1}\right)$ of free lipase. ${ }^{34}$ The highest $E_{\mathrm{a}}$ of free lipase was due to the agglomerate in hydrophobic solvent and great mass transfer of reaction system. The higher $E_{\mathrm{a}}$ of benzyl cinnamate preparation using immobilized Novozym 40086 was

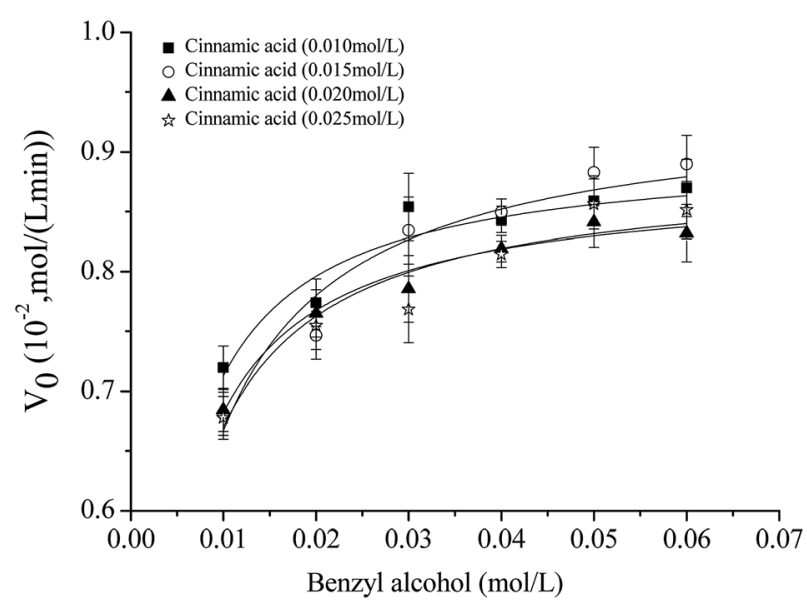

Fig. 8 Non-linear fitting curves between initial esterification rate with the concentration of benzyl alcohol at different cinnamic acid concentrations $\left(0.01 \mathrm{~mol} \mathrm{~L}^{-1}, 0.015 \mathrm{~mol} \mathrm{~L}^{-1}, 0.02 \mathrm{~mol} \mathrm{~L}^{-1}\right.$, $0.025 \mathrm{~mol} \mathrm{~L}^{-1}$ ). Reaction conditions: benzyl alcohol concentrations ranging from $0.01 \mathrm{~mol} \mathrm{~L}^{-1}$ to $0.06 \mathrm{~mol} \mathrm{~L}^{-1}$ at $150 \mathrm{rpm}$ and $40{ }^{\circ} \mathrm{C}$ in isooctane. 
Table 2 ANOVA analysis for response surface models of benzyl cinnamate yield

\begin{tabular}{|c|c|c|c|c|c|}
\hline Sources & Sum of squares & Freedom & Mean square & $F$ Value & Prob $>F$ \\
\hline Model & 7266.35 & 9 & 807.37 & 21.36 & 0.0003 \\
\hline Residual & 264.57 & 7 & 37.80 & & \\
\hline Lack of fit & 241.93 & 3 & 80.64 & 14.25 & 0.0133 \\
\hline Pure error & 22.64 & 4 & 5.66 & & \\
\hline Cor. total & 7530.93 & 16 & & & \\
\hline$R^{2}=0.9649$ & & & & & \\
\hline
\end{tabular}

attributed to the greater stearic hindrance of cinnamic acid than that of vinyl propionate. Arrhenius equation of benzyl cinnamate formation was $\ln V_{0}=1.0787-1799 / T$.

According to the previous methods, ${ }^{47,48}$ non-linear fitting curves at different concentrations of cinnamic acid were achieved (Fig. 8), and initial reaction rate was described as follows:

$$
V=\frac{V_{\max }[\mathrm{A}][\mathrm{B}]}{k_{\mathrm{mB}}[\mathrm{A}]+K_{\mathrm{mA}}[\mathrm{B}]+[\mathrm{A}][\mathrm{B}]}
$$

where $V$ and $V_{\max }$ are initial and maximum esterification rates, respectively; [A], [B], $K_{\mathrm{mA}}$ and $K_{\mathrm{mB}}$ are the concentrations and apparent Michaelis constants of cinnamic acid and benzyl alcohol, respectively. (a)

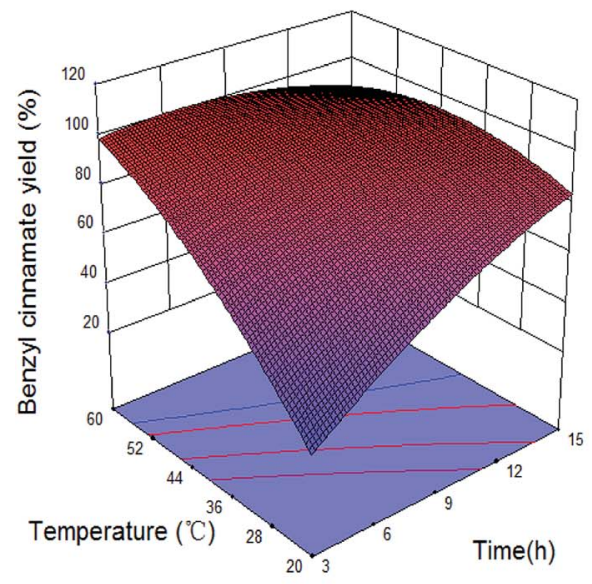

(b)

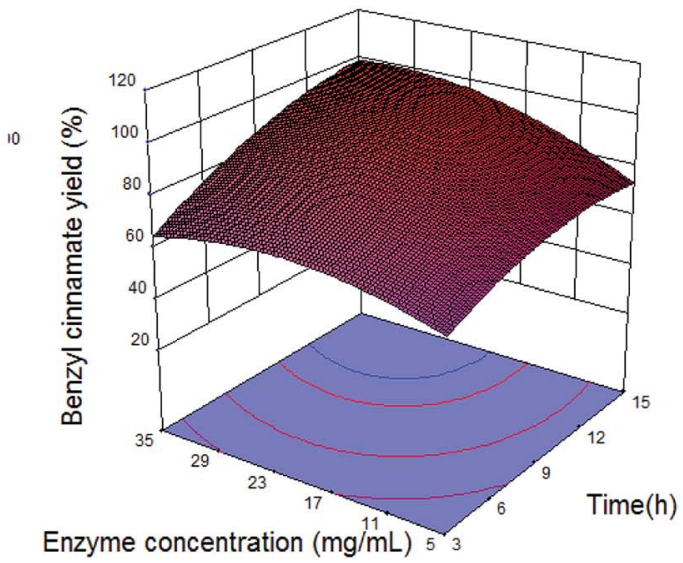

(c)

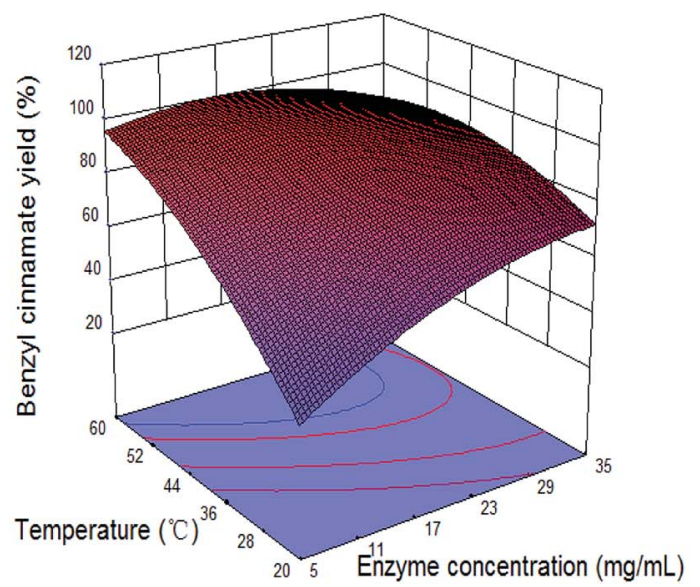

Fig. 9 3D graphs between two parameters for benzyl cinnamate formation: (a) reaction time and temperature with $20 \mathrm{mg} \mathrm{mL}^{-1} \mathrm{Novozym}$ 40086 concentration; (b) Novozym 40086 concentration and time at $40{ }^{\circ} \mathrm{C}$; (c) Novozym 40086 concentration and temperature at 9 h. 


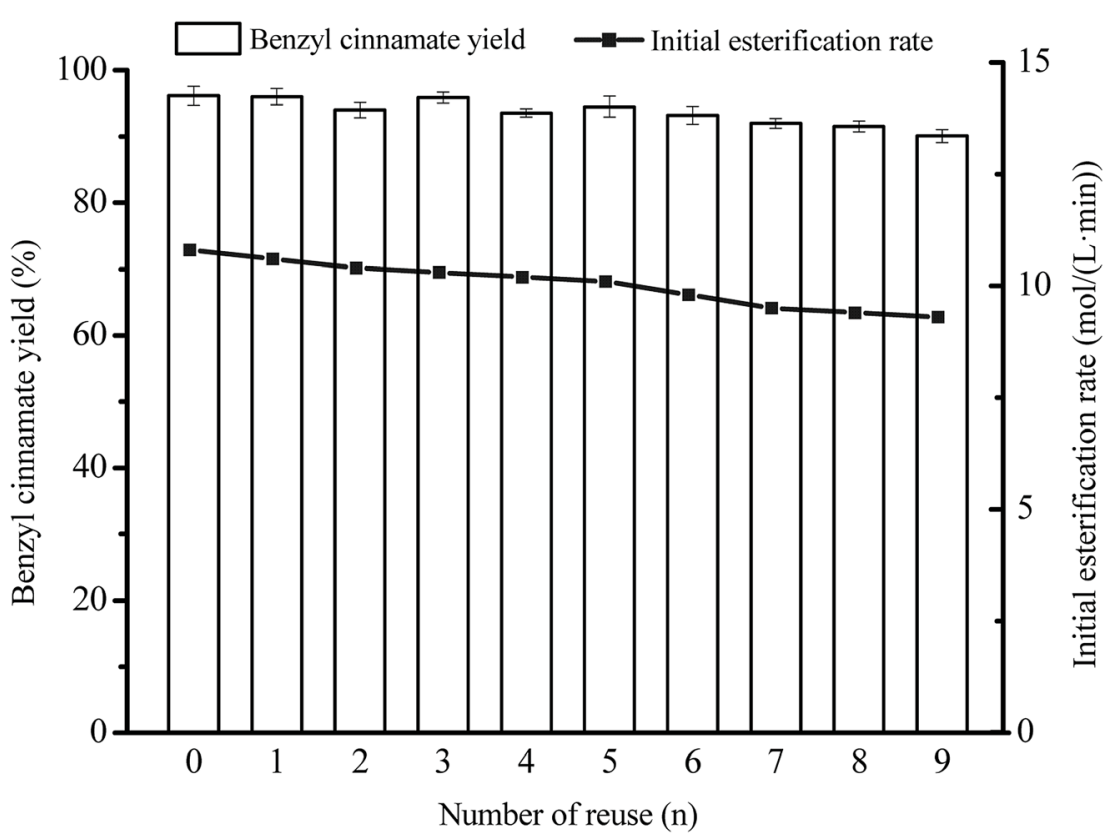

Fig. 10 Reusability of Novozym 40086 in the esterification. Reaction conditions: substrate ratio $1: 3$, Novozym 40086 concentration 23.1 mg $\mathrm{mL}^{-1}$ at $150 \mathrm{rpm}$ and $46.3^{\circ} \mathrm{C}$ in isooctane.

From Fig. 8, $V_{\mathrm{max}}, K_{\mathrm{mA}}$ and $K_{\mathrm{mB}}$ can be calculated as $9.0 \times$ $10^{-3} \mathrm{~mol}\left(\mathrm{~L}^{-1} \mathrm{~min}^{-1}\right), 3.2 \times 10^{-3} \mathrm{~mol} \mathrm{~L}^{-1}$ and $1.2 \times$ $10^{-3} \mathrm{~mol} \mathrm{~L}^{-1}$, respectively.

\subsection{Model fitting}

RSM is an empirical modeling technique used to evaluate the relationship between a set of controllable experimental factors and observed results. Modeling of esterification variables and benzyl cinnamate yield was performed by RSM to predict the highest possible yield of benzyl cinnamate. The results obtained for the models are listed in Tables 1 and 2. For benzyl cinnamate formation, the coefficient of the RSM model was 0.9649 (Table 2), which indicated that the model for benzyl cinnamate formation can successfully predict the relationship between benzyl cinnamate yield with reaction variables. Therefore, the quadratic polynomial model can be obtained from RSM as follows:

Benzyl cinnamate yield $(\%)=89.18+11.97 X_{1}+7.54 X_{2}+19.30 X_{3}$

$$
\begin{aligned}
+5.25 X_{1} X_{2}-16.98 X_{1} X_{3} & -11.98 X_{2} X_{3}-6.24 X_{1}^{2}-8.54 X_{2}^{2} \\
& -8.51 X_{3}^{2}
\end{aligned}
$$

The mutual interactions of three reaction factors on benzyl cinnamate yield were shown in Fig. 9. Benzyl cinnamate yield increased with the increases of reaction variables, and the maximal benzyl cinnamate yield appeared at $40-50{ }^{\circ} \mathrm{C}, 9-12 \mathrm{~h}$, and $>20 \mathrm{mg} \mathrm{mL}^{-1}$ Novozym 40086 concentration. For benzyl cinnamate formation, the effect of esterification parameters was temperature $>$ reaction time $>$ Novozym 40086 concentration (Fig. 9).

\subsection{Optimum esterification parameters and model verification}

In order to test the reliability of the optimization results, the verification experiments were carried out. Result shows that there was no significant difference between the experimental yield $(96.2 \pm 1.4 \%)$ with the theoretical predicted yield (96.9\%), which confirms the validity of the prediction model. Under the optimal conditions: temperature $46.3{ }^{\circ} \mathrm{C}$, Novozym 40086 concentration $23.1 \mathrm{mg} \mathrm{mL}^{-1}$, molar ratio $1: 3$, reaction time $11.3 \mathrm{~h}$, the yield of benzyl cinnamate reached $96.2 \pm$ $1.4 \%$, which was similar with the benzyl cinnamate yields (97\%) in the previous reports. ${ }^{\mathbf{1 0 , 1 2}}$ However, the time to achieve the maximum yield in our work $(11.3 \mathrm{~h})$ was less than half of the previous reports $(\geq 24 \mathrm{~h}) \cdot{ }^{\mathbf{1 0 , 1 2}}$ And the Novozym 40086 concentration $\left(23.1 \mathrm{mg} \mathrm{mL}^{-1}\right)$ used in the work was lower than the previous reports $\left(31 \mathrm{mg} \mathrm{mL} \mathrm{m}^{-1}\right) .{ }^{\mathbf{1 0 , 1 2}}$

\subsection{Reusability of Novozym 40086 in isooctane}

Fig. 10 shows that, under the optimized esterification conditions by RSM, Novozym 40086 can be reused 9 times without obvious benzyl cinnamate yield decrease, and benzyl cinnamate yield $(90.1 \pm 1.2 \%)$ was still higher than $90 \%$ at ninth time. The reuse time ( 9 times) of Novozym 40086 and benzyl cinnamate yield ( $90 \%$ at ninth time) in our work were great higher than that of Lipozyme TLIM (61.3\% benzyl cinnamate yield at third time). ${ }^{10}$ The good reusability of Novozym 40086 was ascribed to the interfacial activation of the immobilized hydrophobic support (acrylic resin beads). Similar influence of hydrophobic support on the lipase activity can also be found in the immobilization of other lipases. ${ }^{19,20,24}$ 


\section{Conclusions}

In this paper, Novozym 40086 was successfully used as a novel biocatalyst to catalyze the esterification for benzyl cinnamate preparation. High yield of benzyl cinnamate $(96.2 \pm 1.4 \%)$ was achieved under the optimized conditions: temperature $46.3{ }^{\circ} \mathrm{C}$, Novozym 40086 concentration $23.1 \mathrm{mg} \mathrm{mL}^{-1}$, molar ratio $1: 3$, reaction time $11.3 \mathrm{~h}$. Under these conditions, Novozym 40086 can be used 9 times without obvious benzyl cinnamate decrease. $E_{\mathrm{a}}$ of benzyl cinnamate formation was $14.96 \pm$ $0.25 \mathrm{~kJ} \mathrm{~mol}^{-1}$. These indicated Novozym 40086 is a good alternative for benzyl cinnamate preparation.

\section{Conflicts of interest}

There are no conflicts to declare.

\section{Acknowledgements}

We profoundly appreciate financial support from National Natural Science Foundation of China (31771937).

\section{References}

1 A. Guniakrzyżak, K. Słoczyńska, J. Popiół, P. Koczurkiewicz, H. Marona and E. Pekala, Int. J. Cosmet. Sci., 2018, 40, 356366.

2 S. Adisakwattana, Nutrients, 2017, 9, 163.

3 G. R. Silveira, K. A. Campelo, G. Lima, L. P. Carvalho, S. S. Samarao, O. Vieira-da-Motta, L. Mathias, C. R. R. Matos, I. J. C. Vieira, E. J. T. de Melo and E. J. Maria, Molecules, 2018, 23, 774.

4 S. P. Bhatia, G. A. Wellington, J. Cocchiara, J. Lalko, C. S. Letizia and A. M. Api, Food Chem. Toxicol., 2007, 45, S40-S48.

5 A. Aliboni, A. D'Andrea and P. Massanisso, J. Agric. Food Chem., 2011, 59, 282-288.

6 M. S. Shintre, R. S. Ghadge and S. B. Sawant, Biochem. Eng. J., 2002, 12, 131-141.

7 G. D. Yadav and S. Devendran, Process Biochem., 2012, 47, 496-502.

8 A. G. A. SÁ, A. C. de Meneses, P. H. H. de Araújo and D. de Oliveira, Trends Food Sci. Technol., 2017, 69, 95-105.

9 S. M. Jakovetic, B. Z. Jugovic, M. M. Gvozdenovic, D. I. Bezbradica, M. G. Antov, D. Z. Mijin and Z. D. Knezevic-Jugovic, Appl. Biochem. Biotechnol., 2013, 170, 1560-1573.

10 Y. Wang, D. H. Zhang, N. Chen and G. Y. Zhi, Bioresour. Technol., 2015, 198, 256-261.

11 M. Dellagreca, L. Previtera, R. Purcaro and A. Zarrelli, J. Nat. Prod., 2007, 70, 1664-1667.

12 D. H. Zhang, J. Y. Zhang, W. C. Che and Y. Wang, Food Chem., 2016, 206, 44-49.

13 K. Huang, Y. Li, C. Kuo, Y. Twu and C. Shieh, Molecules, 2016, 21, 478.

14 M. Adnan, K. Li, L. Xu and Y. Yan, Catalysts, 2018, 8, 96.
15 N. Nobakht, M. A. Faramarzi, A. Shafiee, M. Khoobi and E. Rafiee, Int. J. Biol. Macromol., 2018, 113, 8-19.

16 S. Huang, P. Wu, J. Chen, C. Kuo and C. Shieh, Catalysts, 2018, 8, 338.

17 W. Tischer and V. Kasche, Trends Biotechnol., 1999, 17, 326335.

18 R. C. Rodrigues, C. Ortiz, Á. Berenguer-Murcia, R. Torres and R. Fernández-Lafuente, Chem. Soc. Rev., 2013, 42, 6290-6307.

19 J. C. S. dos Santos, O. Barbosa, C. Ortiz, A. Berenguer-Murcia, R. C. Rodrigues and R. Fernandez-Lafuente, ChemCatChem, 2015, 7, 2413-2432.

20 E. A. Manoel, M. Pinto, J. C. S. dos Santos, V. G. TaciasPascacio, D. M. G. Freire, J. C. Pinto and R. FernandezLafuente, RSC Adv., 2016, 6, 62814.

21 E. P. Cipolatti, E. A. Manoel, R. Fernandez-Lafuente and D. M. G. Freire, Biotechnology Research and Innovation, 2017, 1, 26-34.

22 N. Paludo, J. S. Alves, C. Altmann, M. A. Z. Ayub, R. Fernandez-Lafuente and R. C. Rodrigues, Ultrason. Sonochem., 2015, 22, 89-94.

23 L. P. Fallavena, F. H. F. Antunes, J. S. Alves, N. Paludo, M. A. Z. Ayub, R. Fernandez-Lafuente and R. C. Rodrigues, $R S C$ Adv., 2014, 4, 8675.

24 E. A. Manoel, J. M. Robert, M. C. C. Pinto, A. C. O. Machado, M. D. Besteti, M. A. Z. Coelho, A. B. C. Simas, R. FernandezLafuente, J. C. Pinto and D. M. G. Freire, $R S C A d v .$, 2016, 6, 4043.

25 E. A. Manoel, J. C. S. dos Santos, D. M. G. Freire, N. Rueda and R. Fernandez-Lafuente, Enzyme Microb. Technol., 2015, 71, 53-57.

26 M. Pöhnlein, R. Hausmann, S. Lang and C. Syldatk, Eur. J. Lipid Sci. Technol., 2015, 117, 145-155.

27 Z. Yang, Z. Guo and X. Xu, Food Chem., 2012, 132, 1311-1315.

28 M. D. Romero, L. Calvo, C. Alba and A. Daneshfar, J. Biotechnol., 2007, 127, 269-277.

29 Y. Zheng, X. M. Wu, C. Branford-White, X. Ning, J. Quan and L. M. Zhu, J. Mol. Catal. B: Enzym., 2009, 58, 65-71.

30 Z. T. Alismaeel, A. S. Abbas, T. M. Albayati and A. M. Doyle, Fuel, 2018, 234, 170-176.

31 R. C. Rodrigues and M. A. Z. Ayub, Process Biochem., 2011, 46, 682-688.

32 M. A. Amani, M. S. Davoudi, K. Tahvildari, S. M. Nabavi and M. S. Davoudi, Ind. Crops Prod., 2013, 43, 40-43.

33 K. S. Hari and N. G. Karanth, Biochim. Biophys. Acta, Biomembr., 2001, 1547, 262-267.

34 K. C. Badgujar and B. M. Bhanage, Ind. Eng. Chem. Res., 2014, 53, 18806-18815.

35 C. Kuo, G. Chen, C. Chen, Y. Liu and C. Shiehd, Process Biochem., 2014, 49, 437-444.

36 S. D. Shinde and G. D. Yadav, Ind. Eng. Chem. Res., 2014, 53, 8706-8713.

37 S. Sun, L. Shan, Y. Liu, Q. Jin, Y. Song and X. Wang, J. Mol. Catal. B: Enzym., 2009, 57, 104-108.

38 D. L. Purich, Contemporary enzyme kinetics and mechanism, Elsevier Science Publishing Co. Inc, San Diego, 3rd edn, 2010.

39 S. Sun and B. Hu, Food Chem., 2017, 214, 192-198. 
40 S. Sun, S. Zhu and Y. Bi, Food Chem., 2014, 158, 292-295.

41 Z. Guo and Y. Sun, Food Chem., 2007, 100, 1076-1084.

42 R. Yuryev, V. Kasche, Z. Ignatova and B. Galunsky, Protein J., 2010, 29, 181-187.

43 W. N. Li, B. Q. Chen and T. W. Tan, Appl. Biochem. Biotechnol., 2011, 163, 102-111.

44 W. J. Sun, H. X. Zhao, F. J. Cui, Y. H. Li, S. L. Yu, Q. Zhou, J. Y. Qian and Y. Dong, Chem. Cent. J., 2013, 7, 1-13.
45 G. D. Yadav and S. B. Dhoot, J. Mol. Catal. B: Enzym., 2009, 57, 34-39.

46 Y. Wang, D. H. Zhang, J. Y. Zhang, N. Chen and G. Y. Zhi, Food Chem., 2016, 190, 629-633.

47 A. Cornish-Bowden and J. T. Wong, Biochem. J., 1978, 175, 969-976.

48 A. Cornish-Bowden, Fundamentals of Enzyme Kinetics, Butterworth \& Co. (Publishers) Ltd., Southampton, 1979. 